\title{
KENCAN ILMIAH: APA YANG BISA DILAKUKAN AKADEMISI UNTUK SEPAKBOLA
}

\author{
Febi Kurniawan \\ Prodi Pendidikan Jasmani Kesehatan dan Rekreasi, Fakultas Keguruan dan Ilmu Pendidikan, Universitas \\ Singaperbangsa Karawang \\ e-mail: febi.kurniawan@fkip.unsika.ac.id
}

\begin{abstract}
Abstrak
Akademisi mempunyai peranan yang sentral dalam kemajuan prestasi sepakbola Indonesia, nilai ilmiah yang dimiliki akademisi adalah integritas yang berpedoman pada ilmu pengetahuan. Akademisi harus benar-benar memahami apa saja yang menjadi persoalan yang sedang dihadapi oleh persepakbolaan Indonesia, dan mampu menginternalisasi nilai-nilai ilmu pengetahuan dalam mengahadapi masalah-masalah tersebut. Artikel ini menguraikan mengenai topik pentingnya menjadi akademisi keolahragaan untuk kemajuan persepakbolaan Indonesia, yang dimana kencan ilmiah ditambahkan dengan metode diskusi yang digunakan terdiri dari diskusi teoritis dan praktis yaitu melaksanakan kencan ilmiah apa yang bisa dilakukan akademisi untuk sepakbola dengan pemateri sesuai dengan bidang keahliannya dari seorang akademisi dan praktisi yang menjelaskan tentang sepakbola.
\end{abstract}

Kata kunci: Akademisi, Sepakbola

\begin{abstract}
Academics have a central role in the advancement of Indonesian football achievements, the scientific value possessed by academics is an integrity that is guided by science. Academics must really understand what are the problems that are being developed by Indonesian football, and be able to internalize the values of science in dealing with these problems. This article describes the topic of the importance of being a sports academic for the advancement of Indonesian football, where 'scientific dating' involves discussion method both theoretical and practical discussion. This is to know what kind of 'scientific dating' that academics can do for football involving some presenters with their field of expertise from academics and practitioners who explains about football.
\end{abstract}

Keywords: Akademics, Football

\section{PENDAHULUAN}

Ilmu pengetahuan dan teknologi menyoroti sisi sains dari olahraga paling populer sejagat ini, hal ini memperlihatkan di era persaingan yang makin sengit karena level persaingan semakin tinggi sehingga diperlukan kajian ilmiah dalam mempelajari dan mengembangkan olahraga sepakbola (Ninok Leksono, 2010). Hal ini menjelaskan bahwa seorang akademisi merupakan bagian yang tidak terpisahkan yang eksistensinya sangat menentukan langkah kemajuan masyarakat, bangsa, dan negara Indonesia ke depan. Sebagai generasi penerus, Akademisi diharapkan mampu memberikan kontribusi sesuai dengan kapasitasnya (Zakaria, 2015). Setelah itu masuk dalam akademisi sepakbola yang menyangkut sisi olahraga,yang dirangkum dari artikel-artikel ilmiah terbaru sepakbola berbagai belahan dunia (mostly from Europe/USA) Informasi yang disajikan diharapkan dapat berguna untuk perkembangan prestasi dan ilmu dari sisi sport medicine dari sepakbola di Indonesia yang sedang (selalu) terpuruk di rangking FIFA. Informasi yang disajikan ditujukan untuk pemain maupun pelatih sepakbola Indonesia dan pihak terkait sehingga pemahaman khususnya dari aspek Sport Science dapat lebih maju di negara tercinta ini (Yustika, 2018).Selain itu diperkuat oleh (Komamdin, 2006) Pembinaan terhadap olahraga ini telah lama dilakukan oleh indukorganisasi sepakbola Indonesia (PSSI), namun masih belum menampakkan prestasi yang menggembirakan.

Pemanfaatan dan penerapan ilmu pengetahuan dan teknologi dalam sepakbola modem mutlak harus sudah dilakukan dalam pembinaan sepakbola. Salah satu faktor yang perlu diperhatikan untuk mewujudkan prestasi sepakbola yang tinggi adalah peran akademisi serta pemanfaatan dan 
penerapan ilmu gizi olahraga yang benar dan profesional. Kebutuhan gizi bagi pemain sepakbola meliputi karbohidrat, lemak, protein, vitamin, mineral, air, dan serat. Pemberian makanan bergizi bagi pemain sepakbola dilakukan pada periode pelatihan, periode pertandingan, dan periode pemulihan. Selain itu muncul sebuah jurnal ilmiah pertama yang menjadi rumah bagi karya ilmiah dengan sepakbola sebagai kajian akademik. Jurnal ilmiah terbitan dari Taylor and Francis ini menangkap sisi humanis dari sepakbola yang efeknya mengglobal. Secara rutin sejak tahun 2000 , Soccer \& Society telah menjadi rumah bagi mereka yang mengkaji olahraga mengolah si kulit bundar secara akademik dengan berbagai perspektif, seperti antropologi-politik dan tentunya sosiologi itu sendiri (Aditya Hasymi, 2021).

Dari penjelasan diatas sangat jelas dan berperannya seorang akademisi olahraga untuk membangun dan mencapai prestasi yang tinggi dalam sepakbola Indonesia. Sehingga tujuan dari kegiatan kencan ilmiah: apa yang bisa dilakukan akademisi untuk sepakbola adalah melihat hubungan antara orientasi masa depan sepakbola dengan semangat dan motivasi seorang akademisi sepakbola sehingga akan memberikan sebuah sumbang saran dan ide-ide kreatif seorang akademisi sepakbola dalam mengembangkan prestasi olahraga sepakbola. Selain itu, kencan ilmiah ini juga bertujuan untuk mempromosikan dan mengenalkan sebuah jurnal sepakbola yang dapat menjadi wadah seorang akademisi dalam kajian akademik olahraga sepakbola dalam proses kemajuannya dan sarana mempublikasikan karya ilmiah seorang akademisi dalam hasil riset ataupun dari sebuah kajian ilmiah sehingga dapat memberikan kontribusi yang positif dalam prestasi olahraga sepakbola.

\section{METODE}

Metode kegiatan ini mengunakan tema sebuah Kencan Ilmiah. Pemilihan metode ini cocok digunakan sehingga dipilih melihat kondisi saat ini dengan menggunakan sistem daring dengan aplikasi zoom meeting. Sistem daring saat ini umumnya digunakan untuk seminar atau kursus pelatihan yang diadakan melalui internet, baik dengan biaya atau gratis. Oleh karena itu, partisipasi tidak terbatas pada lokasi tetap, tetapi membutuhkan akses internet (A \& , I Ketut Suda b, 2020). Kencan Ilmiah ini memberikan sebuah solusi dari kebutuhan pelaksanaan pertemuan yang dilakukan dengan tatap muka oleh seorang pemateri dan peserta pertemuan dengan kondisi tempat yang berjauhan melihat situasi saat ini masih dalam masa pandemi Covid 19 sehingga menerapkan phisical distancing. Kencan memiliki definisi janji untuk saling bertemu di suatu tempat pada waktu yang telah ditentukan bersama sedangkan ilmiah adalah ilmu pengetahuan. Sehingga kencan ilmiah ini dapat di definisikan sebagai janji bertemu untuk membahas ilmu pengetahun.

Kegiatan kencan ilmiah ini mengunakan media zoom dalam pelaksanaannya. Sehingga peserta kencan ilmiah harus menggunakan atau mempunyai aplikasi tersebut. Peserta yang akan mendaftar kegiatan kencan ilmiah ini sangat mudah, peserta hanya tinggal registrasi pada kolom link google form yang telah disediakan panitia dengan mengisi data-data yang diperlukan. Setelah itu, panitia akan mengirimkan alamat zoom meeting, password, dan juga akan mengundang peserta pada group whatsapp lewat email peserta. Oleh sebab itu, peserta diharapkan untuk mengirim alamat email dengan benar. Kencan ilmiah ini dilaksanakan secara gratis, tidak dipungut biaya apapun oleh panitia dan peserta mendapatkan fasilitas berupa ilmu yang bermanfaat dan e-sertifikat.

Kegiatan ini bisa dilaksanakan dengan adanya kerjasama antara pengelola-pengelola jurnal dari RESSI, Sepakbola, S3 PEP 2020 UNY, UNSIKA, Universitas Muhammadiyah Ponorogo. Kegiatan kencan ilmiah ini diikuti oleh 60 peserta dan waktu pelaksanaan kegiatan kencan ilmiah pada tanggal 15 April 2021 pukul 20.00 WIB. Dalam waktu kegiatan kencan ilmiah berlangsung, diharapkan seluruh peserta dapat memperhatikan pemaparan yang disampaikan oleh narasumber dan peserta diwajibkan untuk mematikan (mute) audionya sehingga tidak mengganggu narasumber dalam pemaparan materinya dan pserta lain dalam memperhatikan. Dalam sesi pertama kegiatan ini kedua narasumber menyampaikan materinya dan dilanjutkan sesi kedua yaitu diberikannya waktu tanya jawab. Sesi ini moderator mempersilahkan kepada peserta untuk bertanya kepada kedua narasumber terkait dengan materi yang disampaikan. 


\section{HASIL DAN PEMBAHASAN}

Tahap Awal

Para pencinta sepakbola dan sekaligus para pengelola jurnal untuk memberikan kontribusi Kegiatan kencan ilmiah ini sangat penting dilakukan untuk menyediakan wadah pertemuan ilmiah berupa apa yang bisa dilakukan akademisi untuk sepakbola. Pentingnya kencan ilmiah ini menjadi seorang akademisi yang mempunyai peran dalam sepakbola indonesia, dimulai dari diskusi seorang akademisi olahraga pada sepakbola indonesia sekaligus mempromosikan Jurnal Sepakbola sebagai wadah hasil riset ataupun artikel dalam ruang lingkup sepakbola. Kencan ilmiah apa yang bisa dilakukan akademisi untuk sepakbola ini bagian dari rangkaian kencan ilmiah yang panitia laksanakaan dalam rangkaian tujuan memberikan manfaat atau peran seorang akademisi dalam sepakbola.

\section{KENCAN ILMIAH}

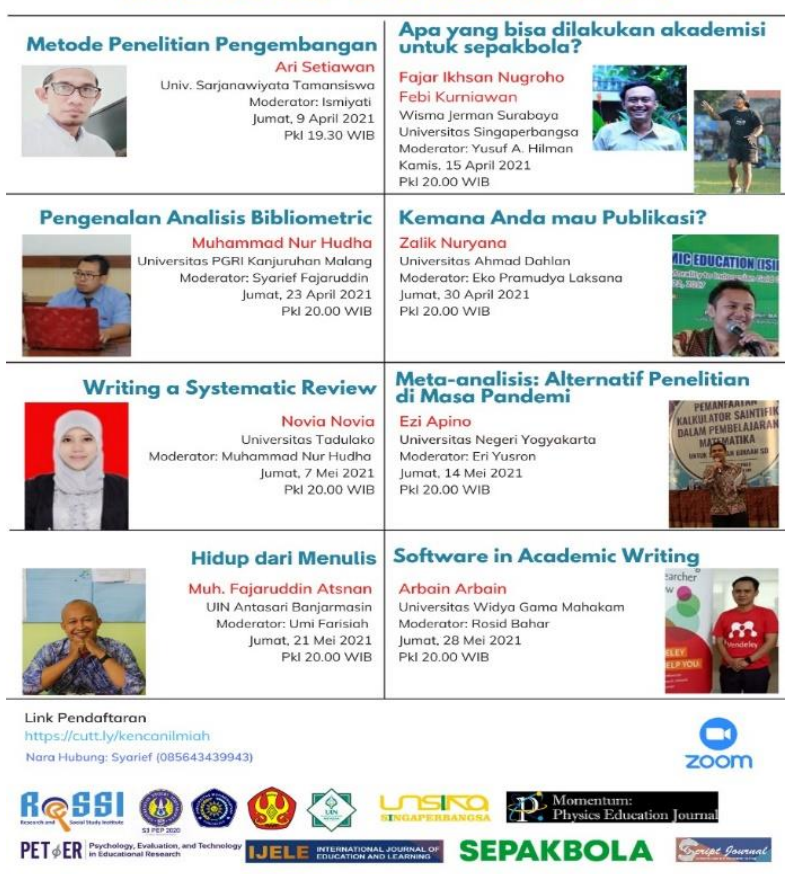

Kencan Ilmiah
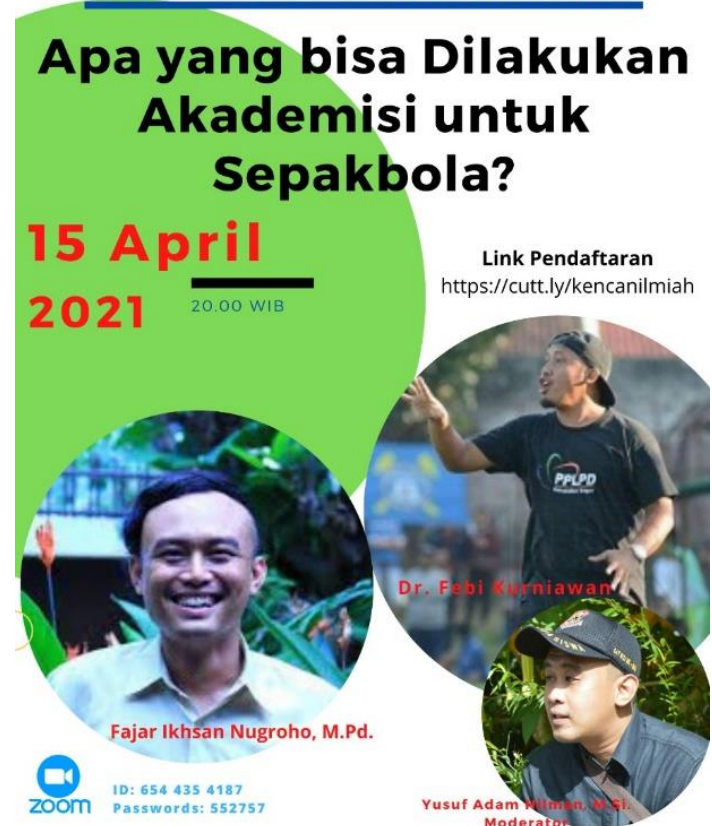

RQSSI SEPAKBOLA

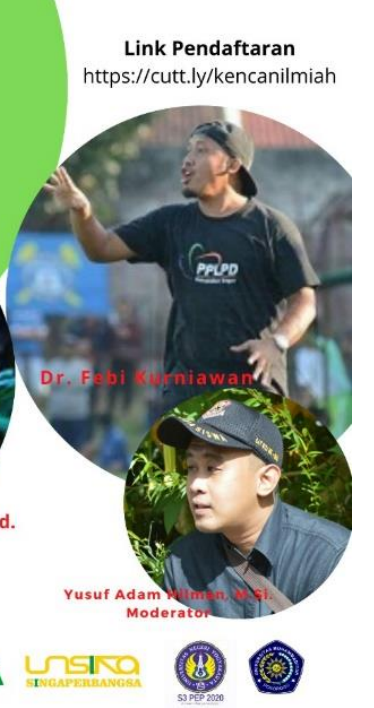

Gambar 1. Pamflet Publikasi Kencan Ilmiah

Tahap Pelaksanaan

Agenda Kencan ilmiah ini diselenggarakan pada hari Kamis, 15 April 2021 pada pukul 20.00 WIB, dipandu oleh panitia yaitu saudara Syarief Fajaruddin dari pihak panitia dan moderator oleh Yusuf Adam dari Universitas Muhammadiyah Ponorogo. Pada saat kegiatan yang dilaksanakan pada malam hari, pembicara menyampaikan materi sepakbola.

Pembicara pertama disampaikan oleh Febi Kurniawan dari Universitas Singaperbangsa Karawang yang menyampaikan materi tenaga keolahragaan dalam sepakbola yang didalamnya terdapat manager, pelatih, wasit, paramedis, tenaga medis, ahli gizi, dan psikolog. Hal ini sesuai dengan persyaratan kompetensi tenaga keolahragaan (PP 16 (87)) dimana terdapat beberapa hal yang terdapat di dalamnya: 1) Pendidikan, diperoleh melalui program pendidikan formal; 2) penataran/pelatihan, diperoleh melalui program penataran/ pelatihan kecabangan olahraga yang terakreditasi; 3) Pengalaman, diperoleh melalui penilaian terhadap frekuensi dan bobot penugasan serta penghargaan yang diterima; 4) Unjuk kinerja, diperoleh melalui uji kompetensi; dan 5) Kelayakan fisik dan mental sesuai dengan ketentuan cabor bersangkutan, diperoleh melalui pengujian medik dan mental.

Pemateri kedua yang disampaikan oleh Fajar Ikhsan Nugroho yang berasal dari wisma Jerman Surabaya sekaligus beliau adalah seorang supoter fanatik Pasopati dan wasit sepakbola memberikan materi berkaitan peluang dan tahapan akademisi dalam berperan di sepakbola. Pemateri menjelaskan tahapan pendidikan yang harus ditempuh untuk menjadi seorang pelatih: 1) Lisensi D Nasional; 2) Lisensi C AFC; 3) Lisensi B AFC; 4) Lisensi A AFC; 5) Lisensi AFC Pro, 
yang setiap orang yang ingin memiliki lisensi AFC Pro harus memiliki lisensi dibawahnya mulai dari lisensi D nasional hingga A AFC. Sedangkan untuk menjadi seorang wasit sepakbola, seseorang harus juga menempuh pendidikan wasit sepakbola dari lisensi C3 (kabupaten/kota), lisensi C2 (daerah/provisnsi), lisensi C1 (nasional), dan FIFA (internasional). Tahapan ini harus ditempuh untuk mendapatkan kompetensi keolahragaan yang sesuai dan dapat aktif dalam profesi olahraga sepakbola. Selain itu pemateri juga menceritakan pengalamannya memimpin pertandingan di jerman dengan menggunakan lisensi yang dia tempuh di Indonesia dan juga bagaimana seorang penegak hukum di lapangan sepakbola diapresiasi dengan baik oleh federasi ataupun klub-klub profesional yang mengikuti liga Jerman.

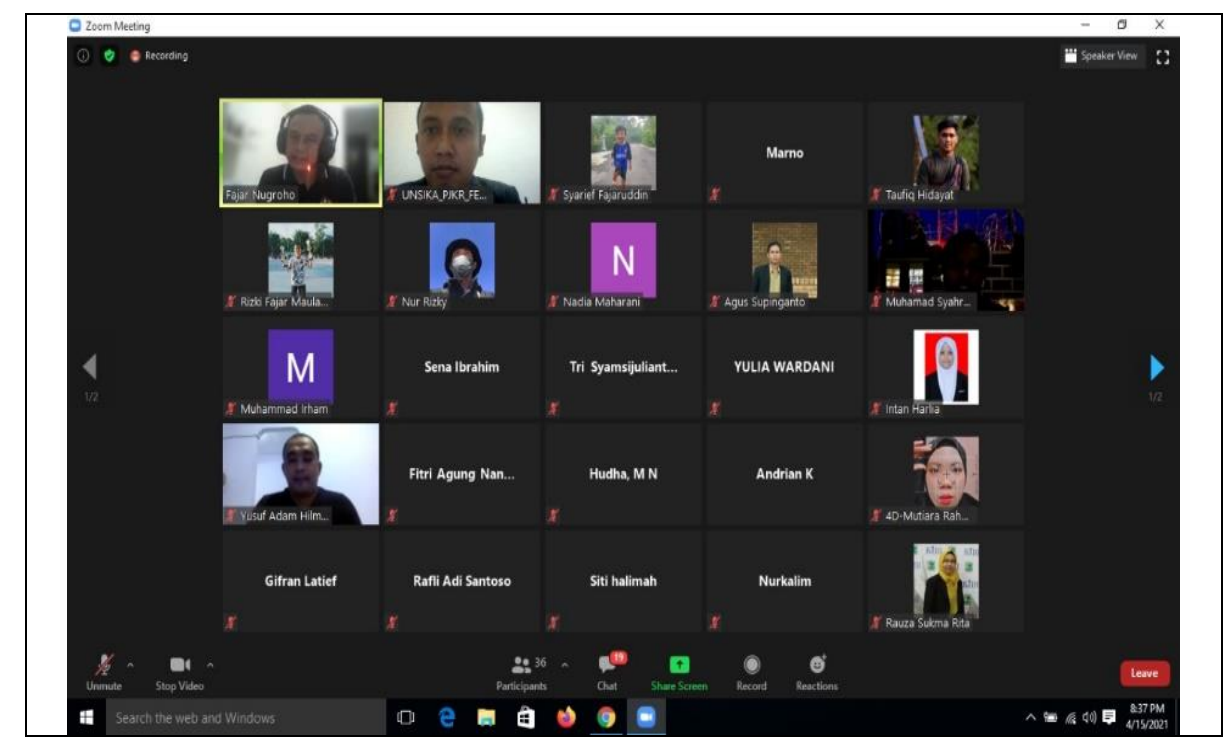

Gambar 2. Pelaksanaan Zoom Meeting Kencan Ilmiah

Sesi selanjutnya adalah sesi tanya jawab, dimana peserta kencan ilmiah menyampaikan pertanyaan-pertanyaan sesuai dengan konteks persoalan yang dihadapi dalam rangka mengindentifikasi permasalahan yang ada disepakbola dalam hal ini adalah peran seorang akademisi. Terdapat setidaknya tiga pertanyaan yang disampaikan peserta dalam rangka mendiskusikan permasalahan yang ada dilapangan dan juga isu yang menarik dan terkini dalam sepakbola profesional. Pertanyaan pertama membahas tentang kesenjangan yang ada dalam lingkungan sepakbola bahwa dibeberapa tim sepakbola profesional kurang welcome terhadap akademisi dalam melaksanakan riset di tim sepakbola dan asosiasi yang menaungi sepakbola disuatu wilayah. Pembahasan ini menyimpulkan bahwa perlunya koordinasi yang baik dari setiap instansi/organisasi sehingga muncul sebuah kepercayaan. Pertanyaan kedua membahas tentang hasil riset yang tidak terpublikasi dan tidak dimanfaatkan dengan baik. Dari diskusi tersebut menyimpulkan bahwa perlunya publikasi dari hasil riset seorang akademisi sepakbola yang dapat bermanfaat secara nyata terhadap prestasi sepakbola Indonesia dan panitia sudah memberikan wadah secara nyata untuk publikasi hasil riset para akademisi dalam mendukung prestasi sepakbola Indonesia (Jurnal Sepakbola/ https://ejournal.ressi.id/index.php/sepakbola).

Diskusi dilanjutkan dari pertanyaan yang ketiga yang membahas tentang berita terkini bahwa munculnya pendatang baru seorang publik figur yang sangat dikenal oleh masyarakat Indonesia bahwa seorang Raffi Ahmad membeli sebuah tim sepakbola profesional yang berkiprah di liga 2 Indonesia. Hal ini menarik menjadi pembahasan oleh seorang peserta kepada pemateri bahawasanya Raffi Ahmad adalah seorang selebriti apakah memberikan kontribusi yang positif kepada persepakbolaan Indonesia. Hasil diskusi ini menyimpulkan bahwasanya ada hal yang menarik perhatian oleh insan sepakbola dengan kehadirannya seorang Raffi Ahmad dalam kepemilikan tim sepakbola profesionalnya yang telah diberi nama RANS Cilegon FC. Hal yang menarik disini adalah warna yang berbeda dalam perkembangan industri sepakbola indonesia yang akan dilakukan Raffi Ahmad dalam managerial timnya dan yang ditunggu-tunggu adalah prestasi 
tim tersebut dan kontribusi prestasi sepakbola Indonesia. Sudut pandang pro dan kontra dari hasil diskusi ini akan memberikan pemahaman yang lebih komprehensif terhadap penyelesaian isu atau masalah yang sedang dihadapi oleh seorang akademisi.

Tahap Akhir

Pada tahap akhir, peserta mendapatkan sertifikat yang menjelaskan mengenai kegiatan yang telah dilaksanakan. Pemateri memberikan kesimpulan umum mengenai hasil dari kencan ilmiah dan kembali memberikan pesan kepada peserta agar seorang akademisi mempunyai kompetensi yang baik dan mempunyai motivasi tinggi dalam membangun sepakbola Indonesia. Peserta diharapkan untuk senantiasa berkontribusi melalui karya dan peran apapun untuk membantu sepakbola Indonesia yang lebih baik dan berprestasi di kancah dunia.

\section{SIMPULAN}

Kencan Ilmiah mengenai apa yang bisa dilakukan akademisi untuk sepakbola menjadi sangat penting untuk dilaksanakan, melihat adanya kesenjangan yang ada dilapangan saat ini, terutama peran seorang akademisi untuk sepakbola indonesia tidak berada pada letak strategis dalam organisasi olahraga sepakbola. Akibat dari hal itu menjadi hal yang tidak mudah masuknya sports science dalam sepakbola Indonesia sehingga lambatnya prestasi sepakbola Indonesia di level Internsional. Pandang pro dan kontra dalam memberikan sumbangsih pemikiran secara ilmiah untuk menyelesaikan masalah bangsa dan negara. Rekomendasi dari hasil.

\section{Saran}

Kencan ilmiah yang dilakukan ini hendaknya memberikan masukan kepada setiap organisasi/instansi olahraga baik di pusat maupun di daerah dapat dapat menjalin kerjasama yang baik dan memberikan kepercayaan kepada para akademisi olahraga khususnya sepakbola agar dapat membantu semaksimal mungkin dalam pencapaian prestasi olahraga sepakbola di Indonesia.

\section{UCAPAN TERIMA KASIH}

Penulis mengucapkan terima kasih kepada para pihak yang mensuport kegiatan ini dengan melaksanakan kerjasama yang baik untuk menyelenggarakan kegiatan kencan ilmiah ini. Pihakpihak yang mensuport adalah pengelola jurnal dari RESSI, Jurnal Sepakbola, S3 PEP 2020 UNY, UNSIKA, dan Universitas Muhammadiyah Ponorogo

\section{DAFTAR PUSTAKA}

A, I. G. D. G., \& , I Ketut Suda b, K. H. P. (2020). Webinar Sebagai Sumber Belajar Di Tengah Pandemi Covid-19. PURWADITA: JURNAL AGAMA DAN BUDAYA, 4(2), 127-132. http://jurnal.stahnmpukuturan.ac.id/index.php/Purwadita/article/view/614

Aditya Hasymi. (2021). Mengkaji Sepak Bola dari Sudut Pandang Sosiologi. Gantigol.Com. https://gantigol.com/blog/post/mengkaji-sepak-bola-dari-sudut-pandang-sosiologi

Komamdin. (2006). Pemenuhan Kebutuhan Gizi Atlet untuk Mencapai Prestasi Sepakbola Indonesia. Jurnal Ilmiah Kesehatan Olahraga, 2(2), 119-134. https://doi.org/https://doi.org/10.21831/medikora.v11i2.4766

Ninok Leksono. (2010). Sepak Bola dan Sainsnya. KOMPAS.COM. https://edukasi.kompas.com/read/2010/07/07/10034537/ Sains $\sim$ Serba Serbi?page=all

Yustika, G. P. (2018). Fisiologi dalam Permainan Sepakbola Profesional: Studi Literatur. Jurnal Pendidikan Olah Raga, 7(1), 22-39. https://doi.org/http://dx.doi.org/10.31571/jpo.v7i1.879

Zakaria, M. (2015). Peran Akademisi dalam Membendung Pengaruh Budaya Negatif Generasi Muda Penerus Bangsa. JURNAL LENTERA, 15(15), 87-93. http://jurnal.umuslim.ac.id/index.php/LTR1/article/view/645 